\title{
Effect of time at pasture combined with restricted indoor feeding on production and behaviour in dairy cows
}

\author{
T. Kristensen ${ }^{1 \dagger}{ }^{\dagger}$ F. Oudshoorn², L. Munksgaard ${ }^{3}$ and K. Søegaard ${ }^{1}$ \\ ${ }^{1}$ Department of Agroecology, Danish Institute of Agricultural Sciences, PO Box 50, DK-8830 Tjele, Denmark; ${ }^{2}$ Department of Agricultural Engineering, Danish \\ Institute of Agricultural Sciences, Schüttesvej 17, DK-8700 Horsens, Denmark; ${ }^{3}$ Department of Animal Health, Welfare and Nutrition, Danish Institute of Agricultural \\ Sciences, PO Box 50, DK-8830 Tjele, Denmark
}

(Received 27 March 2006; Accepted 8 December 2006)

Extremely high nutrient loads have been reported in grazed grassland regimes compared with cutting regimes in some dairy systems that include the use of supplemental feeding. The aim of this study was, therefore, to investigate the effects on productivity and behaviour of high-yielding dairy cows with limited access to indoor feed and restriction in the time at pasture in a continuous stocking system. During a 6-week period from the start of the grazing season 2005, an experiment was conducted with the aim of investigating the effect of restrictive indoor feeding combined with limiting the time at pasture on the productivity and behaviour of high-yielding dairy cows (31.0 $\pm 5.4 \mathrm{~kg}$ energy-corrected milk) in a system based on continuous stocking. The herd was split into three groups allocated to three treatments consisting of 4, 6.5 and $9 \mathrm{~h}$ at pasture, respectively. Each group of cows grazed in separate paddocks with three replicates and was separately housed in a cubicle system with slatted floor during the rest of the day. All cows were fed the same amount of supplement, adjusted daily to meet the ad libitum indoor intake of the cows at pasture for nine hours. The herbage allowance was $1650 \mathrm{~kg}$ dry matter (DM) per ha, and the intake of supplemental feed was $9.1 \mathrm{~kg}$ DM per cow daily. The limitation of the time at pasture to $4 \mathrm{~h}$ in combination with restrictive indoor feeding reduced the daily milk, fat and protein yield and live weight compared with $9 \mathrm{~h}$ of access to pasture. The proportion of time during which the cows were grazing while at pasture increased from 0.64 to 0.86 and the estimated herbage intake per $h$ at pasture decreased from $2547 \mathrm{~g}$ DM to $1398 \mathrm{~g} \mathrm{DM}$, when time at pasture changed from 4 to $9 \mathrm{~h}$. It can be concluded, that in systems with a high herbage allowance, the cow was able to compensate for 0.8 of the reduction in time at pasture by increasing the proportion of time spent grazing and presumably also both the bite rate and mass, although the latter two have not been directly confirmed in the present study.

Keywords: cattle, grazing system, herbage intake, nutrient load, pasture

\section{Introduction}

There are major concerns about nutrient loads in some dairy systems where supplemental feeding in combination with grazing may cause grassland nitrogen $(\mathrm{N})$ surpluses of up to $400 \mathrm{~kg} \mathrm{~N}$ per ha per season (Vérité and Delaby, 2000; Søegaard et al., 2001). Grazing, with cows at pasture for two restricted periods during the day, has been demonstrated to reduce $\mathrm{N}$ pollution (Aarts et al., 2000) but the implementation of this system in commercial farming has been negligible. This is probably connected with the extra workload of doubling the number of times going to and from pasture. Year-round indoor feeding could solve the problem, as less leaching of nitrate is expected in a grass cutting system compared with a grazing system

\footnotetext{
${ }^{\dagger}$ E-mail: Troels.Kristensen@agrsci.dk
}

(Kristensen et al., 2005) but this may compromise animal welfare and also increase the feeding costs for dairy producers. The challenge is therefore to find systems, with one grazing period daily, where the intake of herbage can be maintained, while the nutrient load from manure deposited during pasture time is reduced. This calls for systems where the grazing time is stimulated. If in such a system active grazing time is facilitated, an increased intake of herbage per unit time at pasture, would reduce the deposition of manure relative to the intake of herbage, assuming that defaecation and urination are evenly distributed throughout the day, as found in more extensive grazing systems (White et al., 2001).

The cow will only graze for 0.40 to 0.50 of the time at pasture in traditional systems based entirely on grazing or with minor amounts of feed supplement (Gibb et al., 
2002a). The proportion of time used actively grazing is reduced at a high herbage allowance (Gibb et al., 1999), and as shown by Patterson et al. (1998) the timing of indoor feeding may also affect the activity, at least during the first part of the pasture period.

Herbage intake per unit time is related to the time of day (Gibb et al., 1998; Orr et al., 2001), with the highest intake during morning and evening meals. Limiting the time spent on pasture per day might increase grazing intensity (Jung et al., 2002), as may a high herbage allowance (Pulido and Leaver, 2003). Furthermore, a period without access to feed before grazing will increase the rate of intake (Patterson et al., 1998). However, this effect is primarily observed immediately after start of the pasture period, and diminishes over the day (Patterson et al., 1998; Vaughan et al., 2002). Hernandez-Mendo and Leaver (2004) found that the intake rate during grazing decreased both with shorter and longer time at pasture compared with $10 \mathrm{~h}$ in a system with a combination of indoor ad libitum feeding and grazing for a restricted period.

Information about systems combining restrictions in both indoor feeding and time at pasture is however lacking. It is our hypotheses that high-yielding dairy cows in a system that combines restrictions in feed intake before grazing and restricted time at pasture with a high herbage allowance and high herbage quality can maintain milk production due to higher intake rate and higher relative grazing time during the period at pasture.

The aim of this study was, therefore, to investigate the effects on productivity and behaviour of high-yielding dairy cows with limited access to indoor feed and restriction in the time at pasture in a continuous stocking system.

\section{Material and methods}

The experiment was conducted over a six-week period starting with the grazing season of 2005 on the organic experimental farm Rugballegaard $\left(56^{\circ} \mathrm{N}, 10^{\circ} \mathrm{E}\right)$. Average mean daily temperature during the experiment was $11.5^{\circ} \mathrm{C}$, with an average daily minimum temperature of $9.1^{\circ} \mathrm{C}$ and maximum of $18.5^{\circ} \mathrm{C}$ and an accumulated rainfall of $78 \mathrm{~mm}$. Sunrise was at $0506 \mathrm{~h}$ at the start of the experiment and $0425 \mathrm{~h}$ at the end.

\section{Design}

The herd was split into three groups allocated to three treatments. The treatments were $4(4 \mathrm{~h}), 6.5(6.5 \mathrm{~h})$ and 9 $(9 \mathrm{~h})$ hours at pasture, respectively, defined as the period between the entry of the last cow to the paddock and the departure of last cow from the paddock. Each group of cows grazed in separate paddocks and was housed separately in the three groups in a cubicle system with slatted floors during the rest of the day.

\section{Swards}

Three fields were each divided into three paddocks, giving a total of nine paddocks of 1.5 ha each. Each field was located at different distance from the farm, with average distances of 300,1000 and $1100 \mathrm{~m}$, respectively, to the entrances to the three paddocks. There was no visual contact between the three groups of cows during grazing or from the lanes between the farm and paddock.

The cows grazed in a continuous stocking system. Each treatment group grazed in each field every 3rd day and always in the same paddock. This design was chosen in order to have three replications at field level without introducing bias between treatments and fields. The area of each paddock was adjusted before every second grazing day by moving the electric fence between the grazed part of the paddock and the buffer area with the aim of keeping a sward height of $8 \mathrm{~cm}$ in the grazed part of the paddock. The buffer area was cut for silage 1 and 4 weeks after the start of the experiment.

The pastures were dominated by perennial ryegrass (Lolium perenne) and white clover (Trifolium repens). Estimated from visual inspection every 2nd week, botanic composition was quite different between the three fields (proportion of white clover $0.17,0.19$ and 0.40 , respectively) but without significant difference between paddocks within fields. The average proportion of white clover was $0.24,0.31$ and 0.22 in treatments $4 \mathrm{~h}, 6.5 \mathrm{~h}$ and $9 \mathrm{~h}$, respectively. One of the fields was fertilised with $35 \mathrm{t}$ slurry per ha ( $135 \mathrm{~kg}$ total $\mathrm{N})$ at the beginning of April, while no fertiliser was given to the other fields. One of the fields was a 4th-year grass-clover, where the proportion of weeds, especially dandelion (Taraxacum sp.), was quite high, 0.19 of the herbage mass as an average of the three paddocks.

Compressed sward height was measured once a week in each paddock by a rising plate meter $(30 \times 30 \mathrm{~cm}$, $\left.3.8 \mathrm{~kg} / \mathrm{m}^{2}\right)$, with an intensity of 100 observation per ha, following a trace from the entrance to the back of the paddock. Each observation was classified as grazed or non-grazed based on visual inspection of the herbage.

Herbage was sampled three times during the experiment by cutting $0.25 \mathrm{~m}^{2}$ at $5 \mathrm{~cm}$ stable height. This was done in three places in the grazed part of each paddock. Herbage mass was estimated by weight per sample and herbage quality was analysed on the pooled sample per paddock and day of registration. At the same interval and following the same route a sample was collected in each paddock by hand-plucking the herbage at the height at which cows were observed to graze. Both sample types were analysed by near infrared spectroscopy (NIR) calibrated for N, watersoluble carbohydrates (WSC), in vitro organic digestibility (IVOMD) and neutral-detergent fibre (NDF).

\section{Herd management}

The herd was milked at $0430 \mathrm{~h}$ and $1500 \mathrm{~h}$ in a two by six herringbone milking parlour, with the cows in treatment $9 \mathrm{~h}$ being milked last at the evening milking. In the morning the order of milking was random, as all cows were mixed before milking. After the morning milking the cows were automatically separated into the three groups and 
the groups were led to the pasture at approximately $0630 \mathrm{~h}$ and returned to the farm at approximately $1030 \mathrm{~h}$, $1300 \mathrm{~h}$ and $1530 \mathrm{~h}$ in each of the treatments, respectively.

Based on Danish feeding standards to Holstein Frisian cows yielding $35 \mathrm{~kg}$ milk daily (Strudsholm et al., 1999), an indoor fed ration was formulated that on a daily basis included ad libitum feeding and $160 \mathrm{~g}$ crude protein (CP) per $\mathrm{kg}$ dry matter (DM) in the total DM intake based on 0.60 of the DM intake from pasture. The supplemental feed was mixed on a DM basis by rolled oats $(0.42)$, grassclover silage (0.25), maize silage (0.22), rolled lupine (0.10) and a mineral mix (0.01). The mean DM content was $450 \mathrm{~g} \mathrm{DM}$ per $\mathrm{kg}$ with $690 \mathrm{~g}$ digestible organic matter (DOM), $130 \mathrm{~g} \mathrm{CP}$ and $340 \mathrm{~g}$ NDF per $\mathrm{kg}$ DM. Mineral and microminerals were added to make a complete ration based on a planned intake at pasture of $11.5 \mathrm{~kg} \mathrm{DM}$, as found by Hernandez-Mendo and Leaver (2004) in a system with a 10-h grazing period. The information above is based on samples of silage, lupine and oats taken once weekly from the silo. The samples of lupin and oats were pooled within each type before analysis for nutrient concentration and feed value.

The cows had access to the supplemental feed immediately after housing - in treatment $9 \mathrm{~h}$, though, not until after evening milking. Intake of the mix was measured each day at group level by the difference between the weight of leftovers and the initial weight of the mixed feed. The same amount of supplemental feed was fed in the three treatments on a daily basis. The actual amount was adjusted according to the ad libitum intake in treatment $9 \mathrm{~h}$ the previous day. Ad libitum was defined as 0.20 of the feed left at $2200 \mathrm{~h}$ in the evening. The amount of feed in the trough was assessed daily in each group at $1300 \mathrm{~h}, 1530 \mathrm{~h}, 2200 \mathrm{~h}$ and at $0430 \mathrm{~h}$ the following morning by visual estimation of the proportion left compared with the amount given. This was done in order to estimate the feed-restricted period in each treatment.

\section{Animals}

Sixty Holstein Friesian cows, $96 \pm 58$ days in milk (mean \pm s.d.), with milk yields averaging $31.0 \pm 5.4 \mathrm{~kg}$ energycorrected milk (ECM) and live weights of $592 \pm 62 \mathrm{~kg}$, were randomly allocated to the three treatments within parity $\left(1,2\right.$ and $\left.2^{+}\right)$. The proportion of cows was, respectively, $0.45,0.25$ and 0.30 in each of the three parities. All cows were introduced to pasture 1 week before the start of the experiment, where they grazed in one group in a paddock outside the experimental area. During this week the indoor feed was gradually changed to the composition of the supplemental feed used during the experiment, the amount was reduced to $9.5 \mathrm{~kg} \mathrm{DM}$ and the time at pasture was increased to $6.5 \mathrm{~h}$ daily.

\section{Milk yield and live weight}

Milk yield was determined over one evening and morning milking twice weekly for each cow and representative milk samples were analysed for content of fat, protein, urea and somatic cell count. Live weight was automatically recorded individually after each milking.

\section{Behaviour}

Behavioural observations and recording of grazing intensity were carried out three times for each cow during the experiment, with observations during the time on pasture on the same day in all groups. There were three observers, with the distribution of individual observers balanced across treatments and fields. Registration of grazing intensity was performed 3 days after registration of behaviour, so that the same group of cows was in the same paddock. Ear tags and neck-belt identified the cow by number.

Behaviour at pasture was observed by scan sampling of the activity of each cow every 10 min in the following categories: grazing, walking, lying and standing. Grazing was defined as cows biting or searching for grass with the head just above the grass surface, whilst walking was defined as cows walking with the head clearly above grass surface. Standing was defined as cows not moving their legs for $5 s$, while lying was defined as cows lying on the ground. The number of observations within each category divided by the total number of observations was calculated for each cow, and referred to as the proportion of time spent on each activity.

Grazing intensity was measured by counting the number of bites per cow over two minutes, once every hour during the time at pasture. This gave approximately four, six and eight observations per cow in treatments $4 \mathrm{~h}, 6.5 \mathrm{~h}$ and $9 \mathrm{~h}$, respectively, during one day of observation. The number of observations was dependent on whether the cow was actually grazing during the period of observation. The registration was classified as a regular observation if the cow continued to graze during the $2 \mathrm{~min}$ of observation and as an interrupted observation if the cow stopped grazing for more than $10 \mathrm{~s}$ during the observation. If this was the case, the observation was stopped and the length of grazing, number of bites and the alternative category of behaviour after grazing stopped were noted.

\section{Calculations and statistical analysis}

ECM was calculated according to Sjaunja et al. (1990). Digestibility of organic matter was calculated as $4.10+0.959 \times$ IVOMD (Strudsholm et al., 1999). Metabolisable energy (ME) per $\mathrm{kg}$ DM of herbage and supplemental feed was calculated as $14.2 \times$ $\mathrm{DOM}+5.9 \times \mathrm{CP}$ (Smit et al., 2005). The energy requirements for maintenance, grazing activity, lactation and live-weight change in net energy of lactation (NEL) as described by Macoon et al. (2003) were estimated from animal performance data at group level, as the intake of the indoor feed was registered at group level and converted to $M E$, assuming a utilisation of ME by 0.65 (Agricultural Research Council, 1980). Herbage DM intake was estimated as the difference between the 
requirement and $\mathrm{ME}$ in supplemental feed at group level divided by the ME concentration of the handplucked herbage samples (Pulido and Leaver, 2001).

Sward parameters were analysed by PROC GLM (Statistical Analysis Systems Institute (SAS), 1999) with treatment and field and the interaction between them as fixed effects and simple averages within paddock as dependent variables. The proportion of the paddock that was not grazed by the cows was calculated as the proportion of sward height observation classified as non-grazed in relation to all observations.

PROC MIXED (SAS, 1999) was used to analyse the variance in milk yield, milk content, live weight, grazing behaviour and grazing intensity. Somatic cell count was transformed by $\log _{10}$ in order to obtain normal distribution. Individual weekly average results were tested in a full model with stage of lactation, parity, treatment and week of observation as fixed effects, cow as random effect and yield or live weight prior to start of the experiment as covariates and all interactions to treatment. The final model was reduced for each variable to include only significant interactions $(P<0.05)$.

A model of the live weight of each animal during the experiment was made as a second order regression model with the daily weight data, by use of PROC REG (SAS, 1999). The model parameters for each animal and the daily live weight gain calculated as the difference between the estimated live weight in week 6 and week 1 were tested in a model with stage of lactation, parity and treatment as fixed effects and live weight prior to the start of the experiment as covariate by PROC GLM (SAS, 1999).

\section{Results}

The realised period at pasture was (mean \pm s.e.) $4 \mathrm{~h}$ $5 \mathrm{~min} \pm 4 \mathrm{~min}, 6 \mathrm{~h} 35 \mathrm{~min} \pm 6 \mathrm{~min}$ and $9 \mathrm{~h} 5 \mathrm{~min} \pm 4$ min for each treatment, respectively. One cow was replaced in treatment $9 \mathrm{~h}$ after 16 days, due to a locomotion problem. The replacement cow was not included in the analysis of the individual variables. Data from one cow in treatment $9 \mathrm{~h}$ with a missing value for yield prior to the start of the experiment were also excluded. Cows for insemination were fed indoors during the day of service. Thus, an average of $19.6 \pm 0.8$ cows were at pasture daily with no difference between treatments.

\section{Sward measurements}

Mean sward height, herbage allowance and sward qualities are shown in Table 1. There were no differences between treatments for any of the parameters, except for the proportion of non-grazed area, which decreased with increased time allowed at pasture. The area grazed was $2.94,3.12$ and 3.57 ha in treatments $4 \mathrm{~h}, 6.5 \mathrm{~h}$ and $9 \mathrm{~h}$, respectively, with the area in treatment $9 \mathrm{~h}$ being significantly larger than in the other two treatments.

There was variation $(P=0.01)$ in sward height between the three replicates with average heights of 85,103 and $122 \mathrm{~mm}$, respectively, but no difference between the three paddocks within each replicate. There was variation in sward height and in the proportion of non-grazed area during the experimental period (Figure 1). There was a difference $(P<0.05)$

Table 1 Effect of time at pasture on mean sward characteristics (height, allowance and nutrient content) ${ }^{\dagger}$

\begin{tabular}{|c|c|c|c|c|c|}
\hline & \multicolumn{3}{|c|}{ Treatment } & \multirow[b]{2}{*}{ s.e.d. } & \multirow{2}{*}{$\begin{array}{l}\text { Significance } \\
\text { of treatment }\end{array}$} \\
\hline & $4 \mathrm{~h}$ & $6.5 \mathrm{~h}$ & $9 \mathrm{~h}$ & & \\
\hline Pasture area (ha) & $2.94^{\mathrm{a}}$ & $3.12^{\mathrm{a}}$ & $3.57^{\mathrm{b}}$ & 0.05 & 0.04 \\
\hline \multicolumn{6}{|l|}{ Sward height (mm) } \\
\hline grazed area & 103 & 103 & 98 & 3.2 & 0.58 \\
\hline non-grazed area & 192 & 187 & 176 & 8.9 & 0.41 \\
\hline Non-grazed area, proportion of total area & $0.14^{\mathrm{a}}$ & $0.08^{\mathrm{b}}$ & $0.07^{\mathrm{b}}$ & 0.02 & 0.04 \\
\hline Herbage mass (kg DM per ha) & 1765 & 1643 & 1545 & 223 & 0.80 \\
\hline \multicolumn{6}{|l|}{ Herbage quality - cut at $5 \mathrm{~cm}$ stable height } \\
\hline DOM (g/kg DM) & 748 & 746 & 744 & 8 & 0.95 \\
\hline Crude protein (g/kg DM) & 126 & 137 & 146 & 7 & 0.20 \\
\hline NDF $(g / k g ~ D M)$ & 399 & 404 & 401 & 19 & 0.98 \\
\hline WSC (g/kg DM) & 20.5 & 18.8 & 18.0 & 1.2 & 0.36 \\
\hline \multicolumn{6}{|l|}{ Herbage quality - hand plucked } \\
\hline DOM (g/kg DM) & 754 & 750 & 752 & 9 & 0.94 \\
\hline Crude protein (g/kg DM) & 175 & 180 & 181 & 10 & 0.90 \\
\hline NDF $(g / k g ~ D M)$ & 345 & 362 & 356 & 14 & 0.70 \\
\hline WSC (g/kg DM) & 166 & 156 & 159 & 18 & 0.92 \\
\hline
\end{tabular}

a,b Within a row, values with different letters are significantly different.

${ }^{\dagger}$ Treatments are: $4 \mathrm{~h}=4 \mathrm{~h}$ at pasture; $6.5 \mathrm{~h}=6 \mathrm{~h}$ and $30 \mathrm{~min}$ at pasture; $9 \mathrm{~h}=9 \mathrm{~h}$ at pasture. Other abbreviations are: DM $=$ dry matter; DOM $=$ digestible organic matter; NDF $=$ neutral-detergent fibre; WSC $=$ water-soluble carbohydrates.

${ }^{\ddagger} P$-value for test of significant treatment effect. 

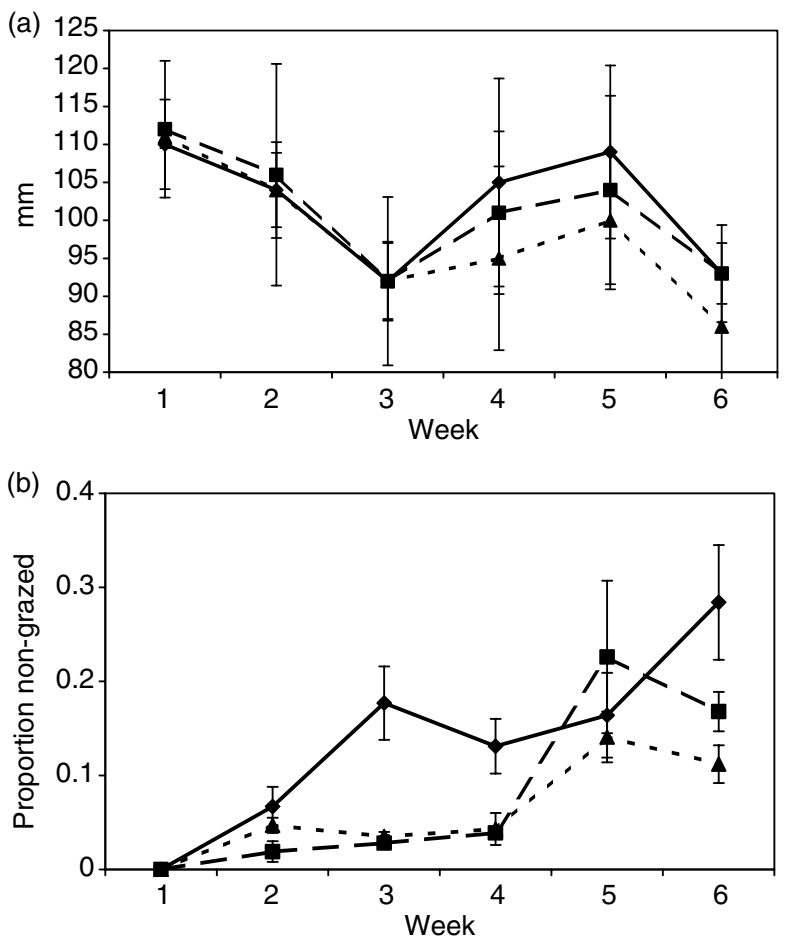

Figure 1 Effect of time at pasture on sward height in (a) the grazed part of the paddock and (b) proportion of non-grazed area in each week during the experiment, mean and s.e. Treatments are: $\bullet=4 \mathrm{~h}$ at pasture; $=6 \mathrm{~h}$ and $30 \mathrm{~min}$ at pasture; $\boldsymbol{\Delta}=9 \mathrm{~h}$ at pasture.

between treatments in the proportion of non-grazed area in weeks 3, 4 and 6 , with the amount in treatment $4 \mathrm{~h}$ being higher than in the other two treatments. The average herbage mass decreased from $2221 \pm 635 \mathrm{~kg}$ DM per ha above $5 \mathrm{~cm}$ in the 2nd week, to $1589 \pm 435 \mathrm{~kg}$ DM per ha in week 4 and $1137 \pm 277 \mathrm{~kg}$ DM per ha in the last week of the experiment.
A test of the difference between the two methods used to estimate the herbage quality showed that the contents of $C P, N D F$ and WSC were affected by the method $(P<0.01)$. This was especially the case for $C P$, where the content was 0.32 higher in the hand-plucked samples than in the cut samples. The content of NDF in the hand-plucked samples increased ( $14.1 \mathrm{~g} /$ week), whereas the WSC content decreased during the experiment $(-24.4 \mathrm{~g} /$ week $)$, as did the DOM $(-8.1 \mathrm{~g} /$ week $)$, while the $\mathrm{CP}$ content did not change between dates of sampling.

\section{Milk yield, content and live weight}

The daily production of milk and ECM was lower $(P<0.05)$ in treatment $4 \mathrm{~h}$ than in treatment $9 \mathrm{~h}$, with treatment $6.5 \mathrm{~h}$ falling in between (Table 2). There was a higher protein yield with increased time allowed at pasture, while the fat yield was lowest in treatment $4 \mathrm{~h}$, but similar for $6.5 \mathrm{~h}$ and $9 \mathrm{~h}$. For ECM there was an interaction between treatment and week of experiment $(P=0.01)$, with a lower yield in treatment $4 \mathrm{~h}$ than in the other two treatments in the last three weeks of the experiment (Figure 2). The persistency in milk yield was not affected by treatment (data not shown).

Fat and protein content did not differ between treatments, whereas the somatic cell count tended to be lowest in treatment $9 \mathrm{~h}$. The number of cows with more than 500000 somatic cells was 4, 5 and 0 for treatments $4 \mathrm{~h}$, $6.5 \mathrm{~h}$ and $9 \mathrm{~h}$, respectively. Urea in milk was in all treatments at a low level, with the lowest level in treatment $4 \mathrm{~h}$.

Average live weight was higher in treatment $9 \mathrm{~h}$ than in the other two treatments. The daily live-weight gain was not significantly different between treatments, despite large differences between treatments. The weight during

Table 2 Effect of time at pasture on daily milk yield, milk composition, mean live weight and daily live-weight gain ${ }^{\dagger}$

\begin{tabular}{|c|c|c|c|c|c|}
\hline & \multicolumn{3}{|c|}{ Treatment } & \multirow[b]{2}{*}{ s.e.d. } & \multirow{2}{*}{$\begin{array}{l}\text { Significance } \\
\text { of treatment }^{\ddagger}\end{array}$} \\
\hline & $4 \mathrm{~h}$ & $6.5 \mathrm{~h}$ & $9 \mathrm{~h}$ & & \\
\hline No. of animals & 20 & 20 & 18 & & \\
\hline Milk (kg/day) & $30.3^{a}$ & $31.3^{\mathrm{a}, \mathrm{b}}$ & $32.4^{\mathrm{b}}$ & 0.7 & 0.007 \\
\hline Fat (g/day) & $1241^{\mathrm{a}}$ & $1324^{\mathrm{b}}$ & $1301^{a, b}$ & 24 & 0.05 \\
\hline Protein (g/day) & $970^{a}$ & $1022^{a, b}$ & $1067^{\mathrm{b}}$ & 23 & 0.05 \\
\hline Milk (kg ECM per day) & $30.1^{\mathrm{a}}$ & $31.8^{\mathrm{b}}$ & $32.1^{\mathrm{b}}$ & 0.5 & 0.01 \\
\hline \multicolumn{6}{|l|}{ Milk composition } \\
\hline Fat content (g/kg milk) & 41.1 & 42.6 & 40.5 & 0.9 & 0.27 \\
\hline Protein content (g/kg milk) & 32.0 & 32.9 & 33.2 & 0.4 & 0.12 \\
\hline Somatic cell count $\left(\times 10^{3}\right)$ & 401 & 360 & 135 & 114 & 0.08 \\
\hline Urea (mmol/l milk) & $2.55^{a}$ & $3.13^{b}$ & $3.03^{b}$ & 0.10 & $<0.001$ \\
\hline Mean live weight (kg) & $579^{a}$ & $583^{\mathrm{a}}$ & $594^{b}$ & 4 & 0.03 \\
\hline Live-weight change (g/day) & 164 & 293 & 483 & 134 & 0.22 \\
\hline
\end{tabular}

\footnotetext{
${ }^{\mathrm{a}, \mathrm{b}}$ Within a row, values with different letters are significantly different.

${ }^{\dagger}$ Treatments are: $4 \mathrm{~h}=4 \mathrm{~h}$ at pasture; $6.5 \mathrm{~h}=6 \mathrm{~h}$ and $30 \mathrm{~min}$ at pasture; $9 \mathrm{~h}=9 \mathrm{~h}$ at pasture. Other abbreviations are: ECM = energy corrected milk.

${ }^{\ddagger} P$-value for test of significant treatment effect.
} 


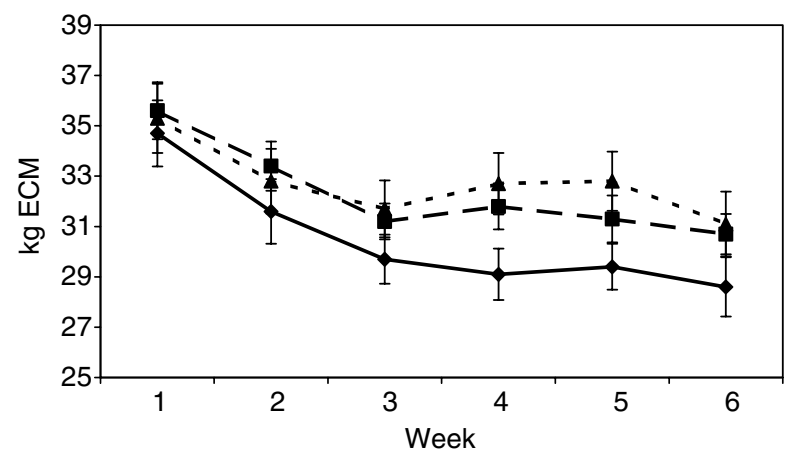

Figure 2 Effect of time at pasture on milk yield of dairy cows, $\mathrm{kg}$ energy-corrected milk (ECM), in each week during the experiment, mean and s.e. Treatments are: $=4 \mathrm{~h}$ at pasture; $\boldsymbol{\square}=6 \mathrm{~h}$ and $30 \mathrm{~min}$ at pasture; $\boldsymbol{\Lambda}=9 \mathrm{~h}$ at pasture.

the experiment was modelled for each treatment:

$$
\begin{aligned}
4 \mathrm{~h}: \quad \mathrm{kg}= & 606 \pm 12-15.0 \pm 2.7 \times \text { week } \\
& +2.3 \pm 0.3 \times \text { week }^{2} \\
6.5 \mathrm{~h}: \quad \mathrm{kg}= & 601 \pm 12-16.2 \pm 2.7 \times \text { week } \\
& +2.6 \pm 0.3 \times \text { week }^{2} \\
9 \mathrm{~h}: \quad \mathrm{kg}= & 587 \pm 13-4.2 \pm 2.7 \times \text { week } \\
& +1.1 \pm 0.3 \times \text { week }^{2}
\end{aligned}
$$

where week $=$ weeks after start of the experiment and $\mathrm{kg}=$ live weight in $\mathrm{kg}$.

The estimates for both week and week ${ }^{2}$ were influenced by treatments $(P=0.01)$, with a difference between treatment $9 \mathrm{~h}$ and the other two treatments. The weight loss was 15 and $14 \mathrm{~kg}$ during the first 3 weeks of the experiment in treatments $4 \mathrm{~h}$ and $6.5 \mathrm{~h}$, respectively, while both the duration and size of weight loss were lower in treatment $9 \mathrm{~h}$ (Figure 3).

\section{Supplemental feed}

The DM intake during housing was $9.3 \mathrm{~kg}$ DM for both treatments $4 \mathrm{~h}$ and $6.5 \mathrm{~h}$, but $0.5 \mathrm{~kg}$ DM lower for treatment $9 \mathrm{~h}$ (Table 3 ), as a result of $0.4 \pm 0.7 \mathrm{~kg}$ DM refused in treatment $9 \mathrm{~h}$. The intake was lowest in weeks 2 and 3 and increased to above $10 \mathrm{~kg}$ DM in the last week, but the daily difference between treatments was low and almost constant during the whole experiment (data not shown). In treatments $4 \mathrm{~h}$ and $6.5 \mathrm{~h}$, less than 0.05 of the feed remained at the inspection in the evening, while 0.2 of the feed remained in treatment $9 \mathrm{~h}$, in agreement with the definition of ad libitum feeding in treatment $9 \mathrm{~h}$. Although the cows came from pastures where they had a high herbage allowance, they always started to eat immediately after returning indoors. By visual inspection it was estimated that 0.15 to 0.25 of the intake of the supplemental

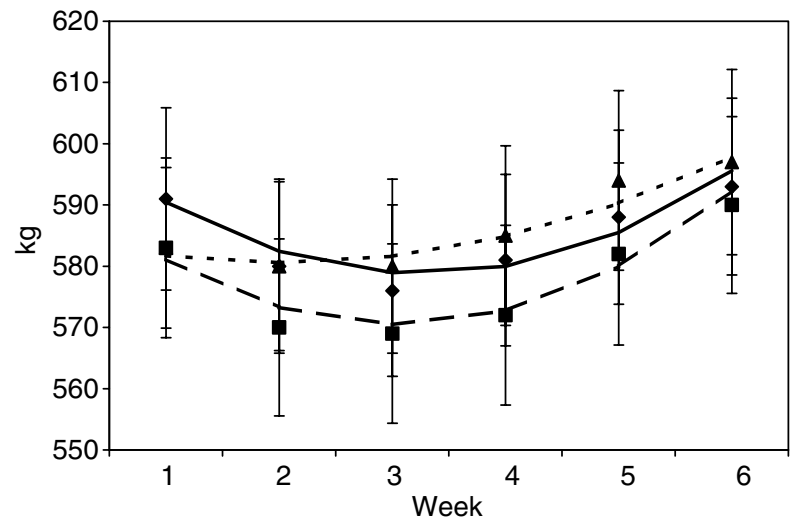

Figure 3 Effect of time at pasture on weekly live weight of the dairy cows. The mean values for each treatment are shown as: $=4 \mathrm{~h}$ at pasture; $\boldsymbol{\square}=6.5 \mathrm{~h}$ at pasture; $\boldsymbol{\Delta}=9 \mathrm{~h}$ at pasture and error bars indicate the s.e. The modelled average for each treatment is shown as: $-=4 \mathrm{~h}$ at pasture; $---=6.5 \mathrm{~h}$ at pasture; $\cdots .=9 \mathrm{~h}$ at pasture.

feed took place during the first hour after housing in both treatments $4 \mathrm{~h}$ and $6.5 \mathrm{~h}$.

\section{Grazing behaviour and intensity}

The proportion of time used on the four different activities in the time budget during the time at pasture differed between treatments (Table 4). The proportion of time spent grazing and walking increased with restriction in time at pasture. The total grazing time was estimated at $3 \mathrm{~h}$ $31 \mathrm{~min}, 5 \mathrm{~h} 8 \mathrm{~min}$ and $5 \mathrm{~h} 49 \mathrm{~min}$ for each treatment, respectively. During the 1 st hour at pasture there were no differences between treatments in the proportion of cows grazing (Figure 4). During the following hours there was a gradual - and with differences between treatments decline in the proportion of cows grazing. In the 2nd hour at pasture, the proportion of cows grazing in treatment $9 \mathrm{~h}$ was lower than in the other two treatments. Although different in level, the trend in the proportion of cows grazing during the day in treatment $6.5 \mathrm{~h}$ and $9 \mathrm{~h}$ was the same, with an increasing grazing activity after 5 to $6 \mathrm{~h}$ at pasture.

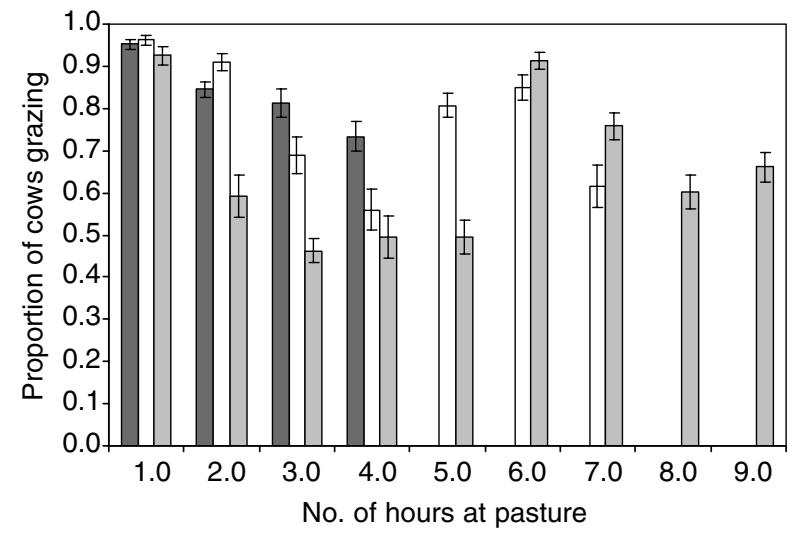

Figure 4 Effect of time at pasture on proportion of cows grazing within each hour after access to pasture, mean and s.e. Treatments are: $\square=4 \mathrm{~h}$ at pasture; $\square=6 \mathrm{~h}$ and $30 \mathrm{~min}$ at pasture; $\square=9 \mathrm{~h}$ at pasture. 
Table 3 Effect of time at pasture on daily intake of supplemental feed, mean $\mathrm{kg}$ dry matter per cow, and proportion of feed left at different hours after feeding, mean and standard error in brackets ${ }^{\dagger}$

\begin{tabular}{|c|c|c|c|c|c|}
\hline & \multicolumn{3}{|c|}{ Treatment } & \multirow[b]{2}{*}{ s.e.d. } & \multirow{2}{*}{$\begin{array}{l}\text { Significance } \\
\text { of treatment }^{\ddagger}\end{array}$} \\
\hline & $4 \mathrm{~h}$ & $6.5 \mathrm{~h}$ & $9 \mathrm{~h}$ & & \\
\hline Feed intake (kg DM per day) & 9.3 & 9.3 & 8.8 & 0.16 & 0.07 \\
\hline Time of feeding & $11: 16 \mathrm{~h}$ & $13: 30 \mathrm{~h}$ & $16: 53 \mathrm{~h}$ & & \\
\hline \multicolumn{6}{|l|}{ Proportion left at: } \\
\hline $12: 56 \mathrm{~h}$ & $0.73(0.05)$ & & & & \\
\hline $14: 35 \mathrm{~h}$ & $0.47(0.05)$ & $0.70(0.08)$ & & & \\
\hline $21: 38 \mathrm{~h}$ & $0.01(0.05)$ & $0.05(0.07)$ & $0.20(0.13)$ & & \\
\hline 04:03 h (next morning) & 0 & 0 & $0.02(0.03)$ & & \\
\hline
\end{tabular}

${ }^{\dagger}$ Treatments are: $4 \mathrm{~h}=4 \mathrm{~h}$ at pasture; $6.5 \mathrm{~h}=6 \mathrm{~h}$ and $30 \mathrm{~min}$ at pasture; $9 \mathrm{~h}=9 \mathrm{~h}$ at pasture. Other abbreviations are: DM $=$ dry matter.

${ }^{\ddagger} P$-value for test of significant treatment effect based on daily intake at group level.

There was no difference in the grazing intensity (bites per min) between the treatments, nor any effect of time of day $(P=0.9)$. The percentage of observations, where grazing was stopped during the 2 min of observation, was higher for treatment $4 \mathrm{~h}$ than for the two other treatments. The grazing intensity was lower $(P<0.001)$ in the interrupted than in the regular observations, without any effect of treatment.

\section{Herbage intake}

Estimated herbage DM intake was $10.4 \mathrm{~kg}$ DM per cow at pasture for $4 \mathrm{~h}$, with an increase of approximately $0.5 \mathrm{~kg}$ DM per $\mathrm{h}$ at pasture to $12.7 \mathrm{~kg} \mathrm{DM}$ in treatment $9 \mathrm{~h}$ (Table 5). The estimated intake per bite and min of grazing were identical for treatments $6.5 \mathrm{~h}$ and $9 \mathrm{~h}$, but higher in treatment $4 \mathrm{~h}$. When intake was related to the realised time at pasture, the highest intake per $\mathrm{h}$ was $2547 \mathrm{~g}$ DM for cows that were at pasture for $4 \mathrm{~h}$, but only $1398 \mathrm{~g}$ DM when they were at pasture for $9 \mathrm{~h}$. The proportions of DM intake from herbage were $0.52,0.55$ and 0.59 in treatments $4 \mathrm{~h}, 6.5 \mathrm{~h}$ and $9 \mathrm{~h}$, respectively.

\section{Discussion}

The cows were at pasture with the planned variation in $\mathrm{h} /$ day between the three treatments and with ad libitum indoor feeding only of the cows with the longest period at pasture, while the other two groups had a period of 6 to $8 \mathrm{~h}$ during housing without access to feed.

\section{Sward allowance and quality}

In addition to sward height, the proportion of rejected area, the quality of herbage and density of the sward have to be considered when measuring herbage allowance (Ungar, 1996). The higher proportion of rejected area in treatment $4 \mathrm{~h}$ indicates a lower utilisation of the herbage growth, but sward heights in the grazed part of the paddock and herbage mass measured from the cuts as well as the quality of the herbage were identical in all treatments, which indicates that all treatments had the same herbage allowance.

The sward height in the grazed part of the paddocks was higher than planned, and showed some variation, both from day to day due to variation between replicates

Table 4 Effect of time at pasture on behaviour and grazing intensity of dairy cows at pasture

\begin{tabular}{|c|c|c|c|c|c|}
\hline & \multicolumn{3}{|c|}{ Treatment $^{\dagger}$} & \multirow[b]{2}{*}{ s.e.d. } & \multirow{2}{*}{$\begin{array}{l}\text { Significance } \\
\text { of treatment }^{\ddagger}\end{array}$} \\
\hline & $4 \mathrm{~h}$ & $6.5 \mathrm{~h}$ & $9 \mathrm{~h}$ & & \\
\hline \multicolumn{6}{|l|}{ Time budget, proportion of total time at pasture } \\
\hline grazing & $0.86^{\mathrm{a}}$ & $0.78^{b}$ & $0.64^{c}$ & 0.02 & $<0.001$ \\
\hline standing & $0.04^{a}$ & $0.09^{b}$ & $0.13^{c}$ & 0.01 & $<0.001$ \\
\hline lying & $0.07^{\mathrm{a}}$ & $0.10^{b}$ & $0.21^{\mathrm{c}}$ & 0.01 & $<0.001$ \\
\hline walking & $0.04^{a}$ & $0.03^{b}$ & $0.02^{c}$ & 0.01 & $<0.001$ \\
\hline \multicolumn{6}{|l|}{ Grazing intensity } \\
\hline Bites per minute, all observations & 54.5 & 56.3 & 55.1 & 1.3 & 0.59 \\
\hline Interrupted observations (\%) & $30^{\mathrm{a}}$ & $20^{\mathrm{b}}$ & $18^{\mathrm{b}}$ & 3 & 0.003 \\
\hline Bites per min, interrupted observations & 48.3 & 47.2 & 46.0 & 1.8 & 0.59 \\
\hline Bites per min, uninterrupted observations & 56.6 & 59.2 & 57.9 & 1.2 & 0.29 \\
\hline Calculated length of grazing (min) & 211 & 308 & 349 & & \\
\hline
\end{tabular}

\footnotetext{
$a, b, c$ Within a row, values with different letters are significantly different.

${ }^{\dagger}$ Treatments are: $4 \mathrm{~h}=4 \mathrm{~h}$ at pasture; $6.5 \mathrm{~h}=6 \mathrm{~h}$ and $30 \mathrm{~min}$ at pasture; $9 \mathrm{~h}=9 \mathrm{~h}$ at pasture

${ }^{\ddagger} P$-value for test of significant treatment effect.
} 
Table 5 Effect of time at pasture on estimated energy demand and daily intake of herbage per cow $^{\dagger}$

\begin{tabular}{lrrr}
\hline \hline & \multicolumn{3}{c}{ Treatment } \\
\cline { 2 - 4 } & $4 \mathrm{~h}$ & $6.5 \mathrm{~h}$ & $9 \mathrm{~h}$ \\
\hline Energy demand (ME MJ) & 221 & 232 & 242 \\
Intake during housing (ME MJ) & 99 & 99 & 93 \\
Estimated intake herbage (ME MJ) & 122 & 133 & 149 \\
Estimated intake herbage (kg DM) & 10.4 & 11.4 & 12.7 \\
Estimated intake herbage (g DM per & 2547 & 1732 & 1398 \\
$\quad$ h at pasture) & & & \\
Estimated intake herbage (g DM per bite) & 0.90 & 0.66 & 0.66 \\
Estimated intake herbage (g DM per & 49 & 37 & 36 \\
$\quad$ min of effective grazing) & & & \\
\hline \hline
\end{tabular}

${ }^{\dagger}$ Treatments are: $4 \mathrm{~h}=4 \mathrm{~h}$ at pasture; $6.5 \mathrm{~h}=6 \mathrm{~h}$ and $30 \mathrm{~min}$ at pasture; $9 \mathrm{~h}=9 \mathrm{~h}$ at pasture. Other abbreviations are: $\mathrm{ME}=$ metabolisable energy; $\mathrm{DM}=$ dry matter.

${ }^{\ddagger}$ Grass quality data from simulated grazing in Table 2 .

$\S$ Grazing intensity from all observation in Table 4.

"Grazing time calculated in Table 4.

and in general during the experiment. The stocking rate of 5.6 to 6.8 cows per ha was low compared with Pulido and Leaver (2003). The low stocking rate may explain the large sward height in the grazed part of the paddocks and not least the increasing proportion of rejected area during the 6 weeks of the experiment. In order to avoid social facilitation between the cows on the different treatments during the pasture period, the paddock was only grazed every $3 d$ day. This might have negatively influenced the utilisation of the herbage growth compared with continuous stocking.

The differences in herbage composition, due to the method of sampling, were in line with Hernandez-Mendo and Leaver (2004) and Pulido and Leaver (2001). The difference in nutrient content for CP and NDF between the cut herbage and the plucked herbage indicates a low defoliation of the herbage DM production (Kristensen, 1988), and therefore also a high selection differential (Pulido and Leaver, 2003). The high DOM of the hand-plucked herbage was similar across treatments, which indicates that all cows across treatments had the opportunity to select highquality feed.

\section{Milk and live weight}

Daily milk production, the amount of protein in the milk and live weight were lower for cows in the $4 \mathrm{~h}$ treatment than in the $9 \mathrm{~h}$ treatment. This is likely to have been due to a combination of restricted supplement feeding and time at pasture, as production was found not to be affected when restriction in time at pasture was combined with ad libitum access to indoor silage (Hernandez-Mendo and Leaver, 2004). It is likely that the lower production is a direct effect of a lower total DM intake at pasture as estimated. The difference of $1.7 \mathrm{~kg}$ ECM between treatments $4 \mathrm{~h}$ and $9 \mathrm{~h}$ is however lower than seen in indoor experiments with restriction in access to feed. This might be explained by the larger diet selection possibility during grazing compared with indoor feeding. As found also by Munksgaard et al. (2005), the cows with to short time for fed intake reduced the live-weight gain in order to meet the demand for milk production.

The protein content was higher in the herbage than in the supplement feed, which potentially induces an asynchronous degradation in the rumen of protein and carbohydrates, and might have a negative effect on milk production, especially for high-yielding cows when the total protein supply is low (Nielsen et al., 2003). The effect on milk yield seems therefore to be related to the lower herbage intake, but might also be influenced by a low protein supply, as indicated by the low urea content in the milk in treatment $4 \mathrm{~h}$.

The experiment was undertaken at the start of the season. In traditional grazing systems the herbage intake and milk yield decrease as the season progresses, even at the same herbage allowance (Kristensen and Aaes, 1999). This might be due to lower palatability of the sward (Spörndly, 1996) or to a general reduction in motivation to feed due to duration of daylight (Leaver, 1985). These effects - as well as the tendency, observed during this experiment, for an increased effect on milk yield of a limitation in the pasture time - indicate that the effect seen over the entire season might be higher than established in this experiment.

\section{Behaviour and grazing intensity}

During the period at pasture there was an effect of the treatments on behaviour, but no effect on grazing intensity. The proportion of the time spent grazing increased, and the proportion of time spent lying and standing decreased with limited time at pasture. Other studies have likewise demonstrated that restricted access to feed can increase eating activity during the following period, where the cows have access to feed at pasture (Patterson et al., 1998) and under housing conditions (Munksgaard et al., 2005). The trend in the time spent grazing is identical to the result of Ayantunde et al. (2001) with calves grazing for 6 to $12 \mathrm{~h} /$ day, while the absolute level is higher than found for dairy cows grazing day and night (Gibb et al., 2002a). Intense grazing activity after morning milking is typical for dairy grazing (Gibb et al., 2002b) and after sunrise in uncontrolled systems (Jung et al., 2002). All cows in our experiment have benefited from this effect, as there was no variation between treatments in the time for turn-out at pasture.

In all treatments the total calculated grazing time was shorter than in previous studies with day and night grazing (Rook et al., 1994; Gibb et al., 2002a). However, the grazing time in treatment $9 \mathrm{~h}$ was higher than the grazing time during daytime for cows on pasture day and night (Rook et al., 1994) and corresponds to the results from Hernandez-Mendo and Leaver (2004) with $10 \mathrm{~h}$ at pasture and $a d$ libitum access to maize silage indoors.

Thus, the results demonstrate that a period with restricted access to feed prior to access to pasture can 
induce a more intensive grazing behaviour, but this was not able fully to compensate for the reduced time at pasture, so the total grazing time was reduced with time at pasture.

The lack of effect on bite rate of time at pasture is in contrast to both Patterson et al. (1998) and Chilibroste et al. (1997) who, besides a negative relation between time at pasture and average bite rate, also found that the intensity declined during the day. Also Gibb et al. (1998) found, that the bite rate was higher in the grazing period following morning milking compared with grazing later in the day, but it is interesting that time of day did not affect total jaw movements. This could explain the missing effect on bite rate, as our method with visual inspection perhaps tended to register jaw movement and not bites. Also the estimated large bite mass in treatment $4 \mathrm{~h}$, both compared with the other two treatments and to the literature (Rook et al., 1994), indicate that the actual bite rate was higher in treatment $4 \mathrm{~h}$.

During a grazing period, cows will typically only have few short periods when the frequent biting of herbage is stopped (Albright, 1993). It is not known why the number of observations with interrupted grazing was larger in treatment $4 \mathrm{~h}$ than in the other two groups. The causal observation of cows walking faster during grazing and cows running along the lane from stable to paddock indicates that the cows had a very high motivation for eating. It was noted that in 0.83 (data not shown) of the interrupted observations, the cow walked after it had stopped grazing. Although not recorded, it was observed that grazing typically started again after only a short break. The estimated large bite mass in treatment $4 \mathrm{~h}$ indicates that this behaviour could be due to short-term physical regulation of the intake.

\section{Intake of herbage}

The herbage intake was estimated from animal performance and standard energy requirement. The advantage of this method compared with the use of the n-alkane (Smit et al., 2005) or the chromium pulse-dose marker method (Macoon et al., 2003) is that it integrates intake response over the entire period of study.

The herbage DM intake estimated in treatment $9 \mathrm{~h}$ is higher than for traditional half-day grazing (Nielsen et al., 2003) or at a similar level (Hernandez-Mendo and Leaver, 2004), which could be an effect of the high allowance and the high initial milk yield (Pulido and Leaver, 2001). The size of the reduction in absolute intake and the increase in intake per hour at pasture in this experiment were higher than recorded for heifers grazing for a limited time (Ayantunde et al., 2001; Ginane and Petit, 2005) but lower than the results of Chilibroste et al. (1997), who compared dairy cows grazing for periods varying from $1 \mathrm{~h}$ to $3 \mathrm{~h} 25 \mathrm{~min}$ after a period of $10 \mathrm{~h}$ without access to feed. The large effect found by Chilibroste et al. (1997) might be an effect of a longer period of starvation and an even shorter time at pasture than in this experiment. Patterson et al. (1998) showed that the intake of herbage increased, if the length of period before pasturing without access to feed was up to $6 \mathrm{~h}$, while a longer period had no further effect on the intake of herbage in the following period at pasture. This could not be confirmed in our study, as the intake increased by $1.3 \mathrm{~kg}$ DM from treatment $4 \mathrm{~h}$ to $6.5 \mathrm{~h}$ and was only reduced to $1.1 \mathrm{~kg}$ DM between treatments $6.5 \mathrm{~h}$ and $9 \mathrm{~h}$.

The DM intake of herbage is a combination of grazing time, bite rate and intake per bite with a compensatory mechanism to maintain intake between the three components, although bite mass has the greatest influence on intake (Bargo et al., 2003). The estimated bite mass was higher for treatment $4 \mathrm{~h}$ than for the other treatments, although the sward height was identical in all treatments. The large sward height supports the potential for an increased bite mass (Gibb et al., 1999) as well as the effect of hunger, as stated by Patterson et al. (1998). This is further underlined by the fact that the bite mass estimated in treatments $6.5 \mathrm{~h}$ and $9 \mathrm{~h}$ is lower than in studies with similar sward height (McGilloway et al., 1999; Pulido and Leaver, 2001).

It can be concluded that in systems with a high herbage allowance, the cow was able to compensate for 0.8 of the reduction in time at pasture by increasing the proportion of time spent grazing and presumably also both rate of biting and bite mass, although the latter two were not directly confirmed in the present study.

\section{Implication}

Restrictions in both indoor feeding and time at pasture effectively increased the active grazing time and the intake of herbage per hour at pasture. This gives positive prospects for the development of systems that reduce nutrient surpluses in grazed grasslands. Before such a system is introduced in commercial dairy farming, further investigation is required to identify ways of reducing the negative impact on daily milk production, examine any effects of season and evaluate the consequences of restricting access to feed for several hours on the welfare of the cows.

\section{Acknowledgements}

The staff at Rugballegaard are gratefully acknowledged for their careful and skilled management of the herd and assistance with the recording.

\section{References}

Aarts HFM, Habekotté B and Van Keulen H 2000. Nitrogen (N) management in the 'De Marke' dairy farming system. Nitrogen Cycling in Agroecosystems 56, 231-240.

Agricultural Research Council 1980. The nutrient requirements of ruminant livestock. CAB, Farnham Royal.

Albright JL 1993. Feeding behavior of dairy cattle. Journal of Dairy Science 76, 485-498.

Ayantunde AA, Fernández-Rivera $\mathrm{S}$, Hiernaux PHY, Van Keulen $H$, Udo HMJ and Chanono M 2001. Effect of timing and duration of grazing of growing cattle in the West African Sahel on diet selection, faecal output, eating time, forage intake and live-weight changes. Animal Science 72, 117-128. 
Bargo F, Muller LD, Kolver ES and Delahoy JE 2003. Invited review: production and digestion of supplemented dairy cows on pasture. Journal of Dairy Science 86, 1-42.

Chilibroste P, Tamminga S and Boer H 1997. Effects of length of grazing session, rumen fill and starvation time before grazing on dry-matter intake, ingestive behaviour and dry-matter rumen pool sizes of grazing lactating dairy cows. Grass and Forage Science 52, 249-257.

Gibb MJ, Huckle CA and Nuthall R 1998. Effect of time of day on grazing behaviour by lactating dairy cows. Grass and Forage Science 53, 41-46.

Gibb MJ, Huckle CA and Nuthall R 2002a. Effect of level of concentrates supplementation on grazing behaviour and performance by lactating dairy cows grazing continuously stocked grass swards. Animal Science 74, 319-335.

Gibb MJ, Huckle CA and Nuthall R 2002b. Effect of level of supplement offered out of parlour on grazing behaviour and performance by lactating dairy cows grazing continuously stocked grass swards. Animal Science 75, 153-167.

Gibb MJ, Huckle CA, Nuthall R and Rook AJ 1999. The effect of physiological state (lactating or dry) and sward surface height on grazing behaviour and intake by dairy cows. Applied Animal Behaviour Science 63, 269-287.

Ginane C and Petit M 2005. Constraining the time available to graze reinforces heifers' preference for sward of high quality despite low availability. Applied Animal Behaviour Science 94, 1-14.

Hernandez-Mendo 0 and Leaver JD 2004. Effect of replacing time available for grazing with time available for eating maize silage and soyabean meal on milk yield and feeding behaviour in dairy cows. Grass and Forage Science 59, 318-330.

Jung J, Yngvesson J and Jensen P 2002. Effects of reduced time on pasture caused by prolonged walking on behaviour and production of Mpwapwa Zebu cattle. Grass and Forage Science 57, 105-112.

Kristensen ES 1988. Influence of defoliation regime on herbage production and characteristics of intake by dairy cows as affected by grazing intensity. Grass and Forage Science 43, 239-251.

Kristensen T and Aaes 0 1999. Interaction between level of contrate supplement, season and stage of lactation on performance of dairy cows on pasture. Acta Agricultura Scandinavia Section A 49, 1-11.

Kristensen T, Søegaard K and Kristensen IS 2005. Management of grasslands in intensive dairy livestock farming. Livestock Production Science 96, 61-73.

Leaver JD 1985. Milk production from grazed temperate grassland. Journal of Dairy Research 52, 313-354.

McGilloway DA, Cushnahan A, Laidlaw AS, Mayne CS and Kilpatrick DJ 1999. The relationship between level of sward height reduction in a rotationally grazed sward and short-term intake rates of dairy cows. Grass and Forage Science 54, 116-126.

Macoon B, Sollenberger LE, Moore JE, Staples CR, Fike JH and Portier KM 2003. Comparison of three techniques for estimating the forage intake of lactating dairy cows on pasture. Journal of Animal Science 81, 2357-2366.

Munksgaard L, Jensen MB, Pedersen LJ, Hansen SW and Matthews L 2005. Quantifying behavioural priorities - effects of time constraints on behaviour of dairy cows, Bos taurus. Applied Animal Behaviour Science 92, 3-14.
Nielsen NM, Kristensen T, Nørgaard P and Hansen H 2003. The effect of low protein supplementation to dairy cows grazing clover grass during half of the day. Livestock Production Science 81, 293-306.

Orr RJ, Rutter SM, Penning PD and Rook AJ 2001. Matching grass supply to grazing patterns for dairy cows. Grass and Forage Science 56, 352-361.

Patterson DM, McGilloway DA, Cushnahan A, Mayne CS and Laidlaw AS 1998. Effect of duration of fasting period on short-term intake rates of lactating dairy cows. Animal Science 66, 299-305.

Pulido RG and Leaver JD 2003. Continuous and rotational grazing of dairy cows - the interactions of grazing system with level of milk yield, sward height and concentrate level. Grass and Forage Science 58, 265-275.

Pulido RG and Leaver JD 2001. Quantifying the influence of sward height, concentrate level and initial milk yield on the milk production and grazing behaviour of continuously stocked dairy cows. Grass and Forage Science 56, 57-67.

Rook AJ, Huckle CA and Penning PD 1994. Effects of sward height and concentrate supplementation on the ingestive behaviour of spring-calving dairy cows grazing grass-clover swards. Applied Animal Behaviour Science 40, 101-112.

Sjaunja LO, Baevre L, Junkkainen L, Pedersen J and Setälä J 1990. A nordic proposal for an energy corrected milk (ECM) formula. In EAAP publication no. 50: performance recording of animals: state of the art, proceedings of the 27th biennial session of the International Committee for Animal Recording (ICAR), Paris 2-6 July (ed. JAM van Arendonk). Wageningen Academic, The Netherlands.

Smit HJ, Taweel HZ, Tas BM, Tamminga S and Elgersma A 2005. Comparison of techniques for estimating herbage intake of grazing dairy cows. Journal of Dairy Science 88, 1827-1836.

Spörndly $E$ 1996. The effect of fouling on herbage intake of dairy cows on late season pasture. Acta Agricultura Scandinavia Section A 46, 144-153.

Statistical Analysis Systems Institute 1999. SAS version 8.1. SAS Institute Inc., Cary, NC, USA.

Strudsholm F, Aaes O, Madsen J, Foldager J, Kristensen VF, Andersen RF, Hvelplund $T$ and Østergaard S 1999. [Danish feed recommendations for cattle.]. Report no 84. The Danish Agricultural Advisory Centre, Skejby. Søegaard K, Lund P, Vinther F, Petersen SO and Aaes 0 2001. Afgræsning med malkekøer. DJF rapport. Markbrug nr. 51.

Ungar ED 1996. Ingestive behaviour. In The ecology and management of grazing systems (ed. J Hodgson and AW Illius), pp. 185-218. Oxford University Press, Oxford.

Vaughan JM, Bertrand JA, Jenkins TC and Pinkerton BW 2002. Effects of feeding time on nitrogen capture by lactating dairy cows grazing rye pasture. Journal of Dairy Science 85, 1267-1272.

Vérité $R$ and Delaby L 2000. Relation between nutrition, performances and nitrogen excretion in dairy cows. Annales de Zootechnic 49, 217-230.

White SL, Sheffield RE, Washburn SP, King LD and Green JT Jr 2001. Spatial and time distribution of dairy cattle excreta in an intensive pasture system. Journal of Environmental Quality 30, 2180-2187. 